https://doi.org/10.48009/1_iis_2010_491-496

\title{
EXAMINING QUANTITY AND TYPE OF COMMUNICATION IN CONTRIBUTING TO IS PROJECT SUCCESS
}

\author{
K. David Smith, Cameron University, davids@cameron.edu \\ Kimberly L. Merritt, Oklahoma Christian University, Kimberly.merrit@oc.edu
}

\begin{abstract}
This paper continues exploring the experience of regional university faculty in implementing experiential learning in various core MIS courses. Clients of past projects were surveyed to determine their perception of project success, the quantity of communication that occurred during the project development stage, and the types of communication that were employed. Analysis of the results indicate that the quantity of communication was significant in predicting the success of the project.

KEYWORDS: experiential learning, communication skills
\end{abstract}

\section{INTRODUCTION}

In previous research, the authors reported on the benefits of experiential learning for students in an MIS curriculum. This approach to student learning was shown to improve the communication skills of students, provide a real-world experience and to increase the students' ability to work cooperatively as part of a project team. The analysis of years of completed projects indicated that when more forms of communication were utilized, and when more communication events occurred, the studentdeveloped projects were more successful.

In this research, the researchers propose to present the results of a client survey. The purpose of the survey is to gain a better understanding of the student-developed project from the perspective of the real-world client. Clients will be surveyed to determine not only their level of satisfaction, but also to determine what forms of communication were utilized between the students and the client. Results of the data collection will be presented and conclusions will be drawn on the importance of communication in the system development process.

\section{LITERATURE REVIEW}

The following is a brief review of the relevant literature. The areas of interest are the need for communication skills in technical graduates, the measurement of user satisfaction with information systems, and the use of experiential learning in information systems' curriculum. For a more detailed literature review of these areas, see Smith and Merritt (2010).

\section{Importance of Communication Skills}

The literature abounds with mandates for social and interpersonal skills (soft skills) in IT/IS graduates. Technical skills are no longer sufficient to land a job, as more than $75 \%$ of job advertisements in technical fields list a requirement for communication and interpersonal skills (Lee, 2005). Employers are increasingly looking for evidence of these skills in the hiring process (Fang, Lee, and Koh, 2005).

\section{User Satisfaction}

While there are many measures of system success (system quality, information quality, use, user satisfaction, individual impact, and organizational impact, (DeLone \& McLean, 1992)), user satisfaction is considered to be the most useful measurement of system success (Chen, Soliman, Mao, \& Frolick, 2000).

\section{Benefits of Experiential Learning}

Experiential learning has been shown to be a win, win, win endeavor. Benefits accrue to the students who complete the projects (Polito, Kros, \& Watson, 2004; Kinsley, 1994; Roberts, 2003; Elbert \& Anderson, 1984; Harris, 1994; Cougar, 1995; Gose, 1997; Jacoby, 1996) the university that provides the opportunity (Cooke \& Williams, 2004; Fox, 2002; Hervani \& Helms, 2004; Stanton, Giles, \& Cruz, 1999; Richards \& Platt, 1992; Johnson, Johnson, \& Smith, 1991; Wedel, Behnezhad, \& Gray, 2004; Cooke \& Williams, 2004), and the business that participates (Fox, 2002; Schuldt, 1991; Cooke \& Williams, 2004). 


\section{METHODOLOGY}

Several Management Information Systems classes use experiential / service learning as a methodology to teach both hard and soft information management skills. Communication skills are one of the most important of the soft skills that must be developed in the students during these classes. Communication techniques used by the students range from face-toface meetings to emails. Over the past eight years, it has become apparent that the amount of communication between students and clients has impacted on the how these databases have been received by the clients. Some of the databases are still in use. Others were never put into use. To attempt to determine whether communication actually played a role in whether database - client use, a simple survey was sent to the primary clients of the various projects. Twenty-two surveys were sent out with fourteen responses received. Survey questions can be found at Appendix 1.

\section{RESULTS}

Based on survey results, the level of communication between students and clients was a one to one match on the how the clients felt regarding the databases success at meeting their expectations. Interestingly, this is borne out in database use category. Communication between students and clients were a mixture of email (10 responses), face-to-face meetings (11), class meetings (9), telephone conversations (7) with only one respondent claiming to have communication with the students from only class meetings. Most clients had multiple types of communication with the students. Four of the clients used four types of communication, four had three, and two had two. The clients that had multiple types of communications with the students ranked the actual success of the database as either a four or five. Four respondents had only single levels of communication - one for email, one for face-to-face, the other two for class meetings only. Two of these respondents ranked the success of the database as a 2 (the lowest score received regarding database success).

According to the respondents, twelve of the fourteen databases are or were used: six databases are still in use, another two are in limited use, four were used but no longer used, and only two were never put into use. The client reasons for not using the database (or no longer using the database) were: the originating client moved; the client chose a different product; the client did not have the funds to hire someone to input the data; and the client changed the requirements and functionality of required by the database.

\section{DATA ANALYSIS}

Several regression analyses were run from the client responses to the online survey questions. In the first, the client's perceived level of communication (number of contacts) significantly predicted the client's perceived level of database success, $\beta=.7814$, $\mathrm{t}(13)=5.481, \mathrm{p}<.05$ (See Table 1$)$.

Table 1

\begin{tabular}{lr}
\hline \multicolumn{2}{c}{ Regression Statistics } \\
\hline Multiple R & 0.845315283 \\
R Square & 0.714557927 \\
Adjusted R & \\
Sqr & 0.690771087 \\
Standard Error & 0.527869144 \\
Observations & 14 \\
\hline
\end{tabular}

\begin{tabular}{|c|c|c|c|c|c|}
\hline & $d f$ & $S S$ & $M S$ & $F$ & $\begin{array}{c}\text { Significance } \\
F \\
\end{array}$ \\
\hline Regression & 1 & 8.3705 & 8.3705 & 30.0401 & 0.0001 \\
\hline Residual & 12 & 3.3438 & 0.2786 & & \\
\hline Total & 13 & 11.7143 & & & \\
\hline
\end{tabular}


Examining Quality and Type of Communication in Contributing to IS Project Success

\begin{tabular}{|c|c|c|c|c|c|c|c|c|}
\hline & Coefficients & $\begin{array}{l}\text { Standard } \\
\text { Error }\end{array}$ & $t$ Stat & P-value & Lower 95\% & $\begin{array}{c}\text { Upper } \\
95 \%\end{array}$ & $\begin{array}{l}\text { Lower } \\
95.0 \% \\
\end{array}$ & $\begin{array}{l}\text { Upper } \\
95.0 \% \\
\end{array}$ \\
\hline Intercept & 0.90625 & 0.6071 & 1.4926 & 0.1613 & -0.4166 & 2.2291 & -0.4166 & 2.2291 \\
\hline $\mathrm{X}$ Variable 1 & $\mathrm{~B}=0.78125$ & 0.1425 & 5.4809 & 0.0001 & 0.4707 & 1.0918 & 0.4707 & 1.0918 \\
\hline
\end{tabular}

In the second regression analysis, the total number of communication methods used did not significantly predict the client's perceived level of database success, $\beta=.4271, \mathrm{t}(13)=1.3317, \mathrm{p}>.05$ (See Table 2).

Table 2

\begin{tabular}{lr}
\hline \multicolumn{2}{c}{ Regression Statistics } \\
\hline Multiple R & 0.358821772 \\
R Square & 0.128753064 \\
Adjusted R & \\
Sqr & 0.056149152 \\
Standard & \\
Error & 1.187682734 \\
Observations & 14 \\
\hline
\end{tabular}

ANOVA

\begin{tabular}{|c|c|c|c|c|c|}
\hline & $d f$ & $S S$ & $M S$ & $F$ & $\begin{array}{c}\text { Significance } \\
F \\
\end{array}$ \\
\hline Regression & 1 & 2.5015 & 2.5015 & 1.7734 & 0.2077 \\
\hline Residual & 12 & 16.9271 & 1.4106 & & \\
\hline Total & 13 & 19.4286 & & & \\
\hline
\end{tabular}

\begin{tabular}{lrrrrrrrr}
\hline & Coefficients & $\begin{array}{c}\text { Standard } \\
\text { Error }\end{array}$ & \multicolumn{1}{c}{ t Stat } & $\begin{array}{c}\text { value } \\
\text { valuer 95\% }\end{array}$ & $\begin{array}{c}\text { Upper } \\
95 \%\end{array}$ & $\begin{array}{c}\text { Lower } \\
95.0 \%\end{array}$ & $\begin{array}{c}\text { Upper } \\
95.0 \%\end{array}$ \\
\hline Intercept & 0.8021 & 1.3661 & 0.5872 & 0.5680 & -2.1743 & 3.7785 & -2.1743 & 3.7785 \\
$\mathrm{X}$ Variable 1 & $\mathrm{B}=0.4271$ & 0.3207 & 1.3317 & 0.2077 & -0.2717 & 1.1259 & -0.2717 & 1.1259 \\
\hline
\end{tabular}

In the third analysis, the client's view of database success significantly predicted the client's impression of the database success, $\beta=2.5, \mathrm{t}(13)=6.5465, \mathrm{p}<.05$ (See Table 3).

Table 3

\begin{tabular}{|c|c|}
\hline \multicolumn{2}{|c|}{ Regression Statistics } \\
\hline Multiple R & 0.88388348 \\
\hline $\begin{array}{l}\text { R Square } \\
\text { Adjusted R }\end{array}$ & 0.78125 \\
\hline $\begin{array}{l}\text { Sqr } \\
\text { Standard }\end{array}$ & 0.76302083 \\
\hline Error & 0.5 \\
\hline
\end{tabular}

Volume XI, No. 1, 2010 
Observations 14

\begin{tabular}{|c|c|c|c|c|c|}
\hline & $d f$ & $S S$ & $M S$ & $F$ & $\begin{array}{c}\text { Significance } \\
F \\
\end{array}$ \\
\hline Regression & 1 & 10.7143 & 10.7143 & 42.8571 & 0.0000 \\
\hline Residual & 12 & 3.0000 & 0.2500 & & \\
\hline Total & 13 & 13.7143 & & & \\
\hline
\end{tabular}

\begin{tabular}{|c|c|c|c|c|c|c|c|c|}
\hline & Coefficients & $\begin{array}{l}\text { Standard } \\
\text { Error }\end{array}$ & $t$ Stat & $P$-value & Lower 95\% & $\begin{array}{c}\text { Upper } \\
95 \%\end{array}$ & $\begin{array}{l}\text { Lower } \\
95.0 \%\end{array}$ & $\begin{array}{l}\text { Upper } \\
95.0 \%\end{array}$ \\
\hline Intercept & -8 & 1.8597 & -4.3019 & 0.0010 & -12.0518 & -3.9482 & -12.0518 & -3.9482 \\
\hline $\mathrm{X}$ Variable 1 & $\mathrm{~B}=2.5$ & 0.3819 & 6.5465 & 0.0000 & 1.6680 & 3.3320 & 1.6680 & 3.3320 \\
\hline
\end{tabular}

In the final analysis, the level of communication significantly predicted the client's impression of the class overall, $\beta=.2805, t(13)=3.3752, p<.05$ (See Table 4).

Table 4

\begin{tabular}{lr}
\hline \multicolumn{2}{c}{ Regression } \\
\hline Multiple R & 0.7332 \\
R Square & 0.5376 \\
Adjusted R & \\
Sqr & 0.4991 \\
Standard & \\
Error & 0.2570 \\
Observations & 14 \\
\hline
\end{tabular}

ANOVA

\begin{tabular}{lrrccc}
\hline & & & & \multicolumn{2}{c}{ Significance } \\
& $d f$ & $S S$ & $M S$ & $F$ & $F$ \\
\hline Regression & 1 & 0.9216 & 0.9216 & 13.9516 & 0.0028 \\
Residual & 12 & 0.7927 & 0.0661 & & \\
Total & 13 & 1.7143 & & & \\
\hline
\end{tabular}

\begin{tabular}{|c|c|c|c|c|c|c|c|c|}
\hline & Coefficients & $\begin{array}{l}\text { Standard } \\
\text { Error }\end{array}$ & $t$ Stat & $P$-value & Lower 95\% & $\begin{array}{c}\text { Upper } \\
95 \%\end{array}$ & $\begin{array}{l}\text { Lower } \\
95.0 \%\end{array}$ & $\begin{array}{l}\text { Upper } \\
95.0 \%\end{array}$ \\
\hline Intercept & 3.6951 & 0.3186 & 11.5982 & 0.0000 & 3.0010 & 4.3893 & 3.0010 & 4.3893 \\
\hline X Variable 1 & $\mathrm{~B}=0.2805$ & 0.0751 & 3.7352 & 0.0028 & 0.1169 & 0.4441 & 0.1169 & 0.4441 \\
\hline
\end{tabular}




\section{LIMITATIONS}

The primary limitation of this study is the small sample size, which limits the extent to which the results can be generalized. Every past client was contacted and asked to complete the survey. Many did. Even so, only two to four projects are undertaken each year and some clients participated in more than one semester project. This limited the number of participants available to take the survey. As new projects are conducted, more surveys will be given and the results added to the existing data. Additionally, it should be noted that the instructor initiated this survey of past clients in the hope of demonstrating the importance of establishing and maintaining communication between the database and capstone students and their clients. To this end, the survey results have been successful.

\section{CONCLUSION}

The data analysis indicates that the more communication between students and clients, the better chance the database will be meet the client's needs and will used or considered successful. Additionally, increased communication lead to a positive impression by the client of both the class and of the completed project. The form of the communication was not found to be important, only that the communication took place.

The increased communication with real clients is also valuable to the students. Soft skills and specifically communication skills are becoming increasingly more important to IT professionals. Providing opportunities for the development of these skills is crucial for any IT curriculum, and crucial for product success. Utilizing experiential / service learning provides a realistic means of developing these skills. As previously stated, experiential learning has been shown to be a win, win, win endeavor, and the results of this research support that assertation.

\section{REFERENCES}

Chen, L., Soliman, K., Mao, E. \& Frolick, M. (2000, April). Measuring user satisfaction with data warehouses: An exploratory study. Information \& Management, 37(3), 103-110.

Cooke, L. and Williams, S. (2004). Two approaches to using client projects in the college classroom. Business Communications Quarterly, 67(2), 139-152.

Cougar, J. D. (1995). Implied creativity no longer appropieate for IS curriculum. Journal of IS Education, 7(1), 12-13.

Volume XI, No. 1, 2010
DeLone W., \& McLean, E. (1992). Information systems success: The quest for the dependent variable. Information Systems Research, 3(1), 60-95.

Elbert, Dennis J. and Anderson, D.G. (1984). Student reaction to local vs. published cases: Is there a difference? Journal of Marketing Education, 6(2), $18-21$.

Fang, X., Lee, S., and Koh, S. (2005). Transition of Knowledge/Skills Requirement for Entry-Level Professionals: An Exploratory Study Based on Recruiters' Perception. Journal of Computer Information Systems, 46(1), 58-70.

Fox, T.L. (2002). A case analysis of real-world systems development experiences of CIS students. Journal of Information Systems Education, 13(4), 343-350.

Gose,B. (1997, November). Many colleges move to link courses with volunteerism: Some critics of service learning question the quality of the service and rigor of the learning. The Chronicle of Higher Education, November, A45.

Harris, Allen L. (1994). Developing the systems project course. Journal of IS Education, 6(4).

Hervani, A. and Helms, M.M. (2004). Increasing creativity in economics: The service learning project. Journal of Education for Business, 267-274.

Jacoby, B. (1996). Service Learning In Higher Education: Concepts and Practices, San Francisco: Jossey-Bass.

Johnson, D.W., Johnson, R.T., and Smith, K.A. (1991). Cooperative learning: Increasing college faculty instructional productivity," ASHE-ERIC Higher Education Report No. 4. Washington, D.C.: School of Education and Human Development, George Washington University.

Kinsley, C.W. (1993). Community service learning as a pedagogy. Equity and Excellence in Education, 26(2), 53-63.

Kinsley, C.W. (1994). What is community service learning? Vital Speeches of the Day. 61(2), 40-43.

Lee, C. K. (2005). Analysis of Skill Requirements for Systems Analysts in Fortune 500 Organizations. Journal of Computer Information Systems, 45(4), 8492.
Issues in Information Systems 
Mitri, M. (2008, Spring). A software development capstone course and project for CIS majors. Journal of Computer Information Systems.

Polito, T., Kros, J. and Watson, K. (2004, May/June). Improving operations management concept recollection via the Zarco experiential learning activity," Journal of Education for Business, 283286

Richards, J. and Platt, H. (1992). Longman Dictionary of Language Teaching and Applied Linguistics. Essex, England: Longman Group UK.

Roberts, G.T. (2003). An interpretation of Dewey's experiential learning theory," Opinion Paper published by New York University through the Institute for Education and Social Policy, 1-9.

Schuldt, B.A. (1991). Real-world versus simulated projects in database instruction. Journal of Education for Business, 67(1), pp. 35-39.

Smith, H., Smarkusky, D., and Corrigall, E. (2008). Defining projects to integrate evolving team fundamentals and project management skills. Journal of Information Systems Education, 19(1), 99-109.

Smith, K. and Clinton, M.S. (2006). Experiential Learning: A Case Study of a Mutually-Beneficial Database Development Project, Issues in Information Systems, 7(1), 24-28.

Smith, K. D. and Merritt, K. (2010). Using experiential learning to develop communication skills and increase user satisfaction with student developed projects, Journal of Research in Information Systems, 3, 2010 .

Stanton, T., Giles, D., and Cruz, N. (1999). Service learning: A Moment's Pioneers Reflect On Its Origins Practice, and Future. San Francisco: JosseyBass.

Wedel, T.L., Behnezhad, A.R., and Gray, G.L. (2004). A data modeling case: Writers guild of
America, east.," Journal of Information Systems Education, 15(1), 13-17.

\section{Appendix 1: Survey Questions}

1. Rank the overall level of communication between the students and you on your project. [ $1-5$ where 1 is bad 5 is excellent]

2. What forms of communication were used between the students and you? (Please choose ALL that apply). [Email, Telephone, Face-to-face, Class Meetings, Class Meetings Only]

3. Rank the level of success for your project. Please base this on whether the project met your expectations and was a usable database. [1 - 5 where 1 is bad 5 is excellent]

4. Is your database still in use? [Still Used, In limited use, Was used but no longer used, Never used]

5. If you never used your database, which best describes why. (You may choose multiple answers). [Database did not meet your requirements (functionality); Individual that requested the database moved; Chose a different product to use; Database difficult to use; Lack of training in the use of the product; Requirements changed - no longer needed the product; Other]

6. If your answer to number 5 was other, please explain.

7. If your database is still in use, what could have been done by the students or faculty to increase the success of the product?

8. From the point of view of the client, please rate your impression of the service learning / experiential learning used in this class. (One for a bad experience - five for a very positive experience).

9. How could we have improved the experience? 